\title{
Skeletal variation in extant species enables systematic identification of New Zealand's large, subfossil diplodactylids
}

\author{
Lachie Scarsbrook ${ }^{*}$, Emma Sherratt $^{2}$, Rodney A. Hitchmough ${ }^{3}$ and Nicolas J. Rawlence ${ }^{1}$
}

\begin{abstract}
New Zealand's diplodactylid geckos exhibit high species-level diversity, largely independent of discernible osteological changes. Consequently, systematic affinities of isolated skeletal elements (fossils) are primarily determined by comparisons of size, particularly in the identification of Hoplodactylus duvaucelii, New Zealand's largest extant gecko species. Here, three-dimensional geometric morphometrics of maxillae (a common fossilized element) was used to determine whether consistent shape and size differences exist between genera, and if cryptic extinctions have occurred in subfossil 'Hoplodactylus cf. duvaucelii'. Sampling included 13 diplodactylid species from five genera, and 11 Holocene subfossil 'H. cf. duvaucelii' individuals. We found phylogenetic history was the most important predictor of maxilla morphology among extant diplodactylid genera. Size comparisons could only differentiate Hoplodactylus from other genera, with the remaining genera exhibiting variable degrees of overlap. Six subfossils were positively identified as H. duvaucelii, confirming their proposed Holocene distribution throughout New Zealand. Conversely, five subfossils showed no clear affinities with any modern diplodactylid genera, implying either increased morphological diversity in mainland 'H. cf. duvaucelii' or the presence of at least one extinct, large, broad-toed diplodactylid species.
\end{abstract}

Keywords: Diplodactylidae, Ecomorphology, Geometric morphometrics, Hoplodactylus duvaucelii, Taxonomy

\section{Background}

New Zealand's lizard fauna is characteristic of isolated archipelagos, exhibiting high species endemism, extensive in situ radiations [1, 2] and insular gigantism [3]. Despite this diversification, the New Zealand Diplodactylids (compared with the New Caledonian radiation) are relatively conserved in form; exhibiting reduced morphological divergence at a similar evolutionary depth $[2,4]$.

Formal taxonomic descriptions of New Zealand diplodactylid species [5, 6], similar to those of Australian [7, 8] and New Caledonian representatives [9-11], have been based exclusively on external morphological characters

\footnotetext{
*Correspondence: lachiescarsbrook@gmail.com

1 Otago Paleogenetics Laboratory, Department of Zoology, University

of Otago, Dunedin, New Zealand

Full list of author information is available at the end of the article
}

(e.g. coloration and scalation), with interspecific skeletal variation rarely analysed. Early anatomical studies [12], however, noted osteological differences between the two then recognized genera: Hoplodactylus ('brown geckos') and Naultinus ('green geckos'); focussing on the neotenic condition of Naultinus and the 'primitive' osteology of the New Zealand Diplodactylidae. Despite these indepth comparisons, re-examination of generic level skeletal variation in the context of current nomenclature is required, given considerable taxonomic fluidity over the last 65 years [13-15].

For example, allozyme $[15,16]$ and mitochondrial DNA $[17,18]$ analyses recognized three species complexes within the genus Hoplodactylus, corresponding to two broad morphological groupings: narrow-toed (H. granulatus and $H$. pacificus) and broad-toed (H. maculatus) clades [19]. Further taxonomic revision [2] separated 
multiple Hoplodactylus species complexes into five genera (Dactylocnemis, Mokopirirakau, Toropuku, Tukutuku and Woodworthia), with Hoplodactylus reserved for $H$. duvaucelii and the extinct giant $H$. delcourti [12]. Conversely, the monophyletic genus Naultinus has been historically over-split, separated into North and South Island genera (Naultinus and Heteropholis respectively; [13]), with Heteropholis later synonymised with Naultinus [19].

Descriptions of these revised genera were based exclusively on external morphology [2]; with osteological differences only recognized for the frontal [21, 22], which has led to assertions of skeletal uniformity at the specieslevel $[23,24]$. In comparison, the identification of interspecific skeletal variation in cranial elements of New Zealand's large eugongyline skinks has enabled both differentiation from smaller congeners [25], and description of the extinct 'giant' Oligosoma northlandi [26, 27] from Holocene subfossil remains. Classification of isolated diplodactylid remains however, has been restricted to size comparisons with extant representatives (in reference to now outdated taxonomy; [23]), particularly in the identification of ' $H$. cf. duvaucelii', New Zealand's largest extant diplodactylid.

Hoplodactylus duvaucelii ('Duvaucel's gecko') is a large, nocturnal species, with a pseudoendemic (realized) distribution on predator-free islands in the Cook Strait and off the north-eastern coast of the North Island (Fig. 1A; [28]). Prior to Polynesian ( 1280 AD; [29]) and European (effectively the late 1700s) arrival, ' $H$. cf. duvaucelii' was widely distributed throughout the North Island [25], and the northwest and eastern South Island (Fig. 1a; [23, 30-33]), evidenced by the presence of large, isolated diplodactylid remains in Holocene predator (laughing owl and falcon) middens. Subsequent range contractions occurred as a result of the synergistic effects of competitive exclusion, direct predation by introduced mammals, and degradation of forest habitat [25, 34]. This extensive distribution across multiple biogeographic regions [23, 35 , given pronounced regional endemism recognised (or proposed) in other New Zealand diplodactylid genera $[1,2]$, combined with the extinction of other large lizards

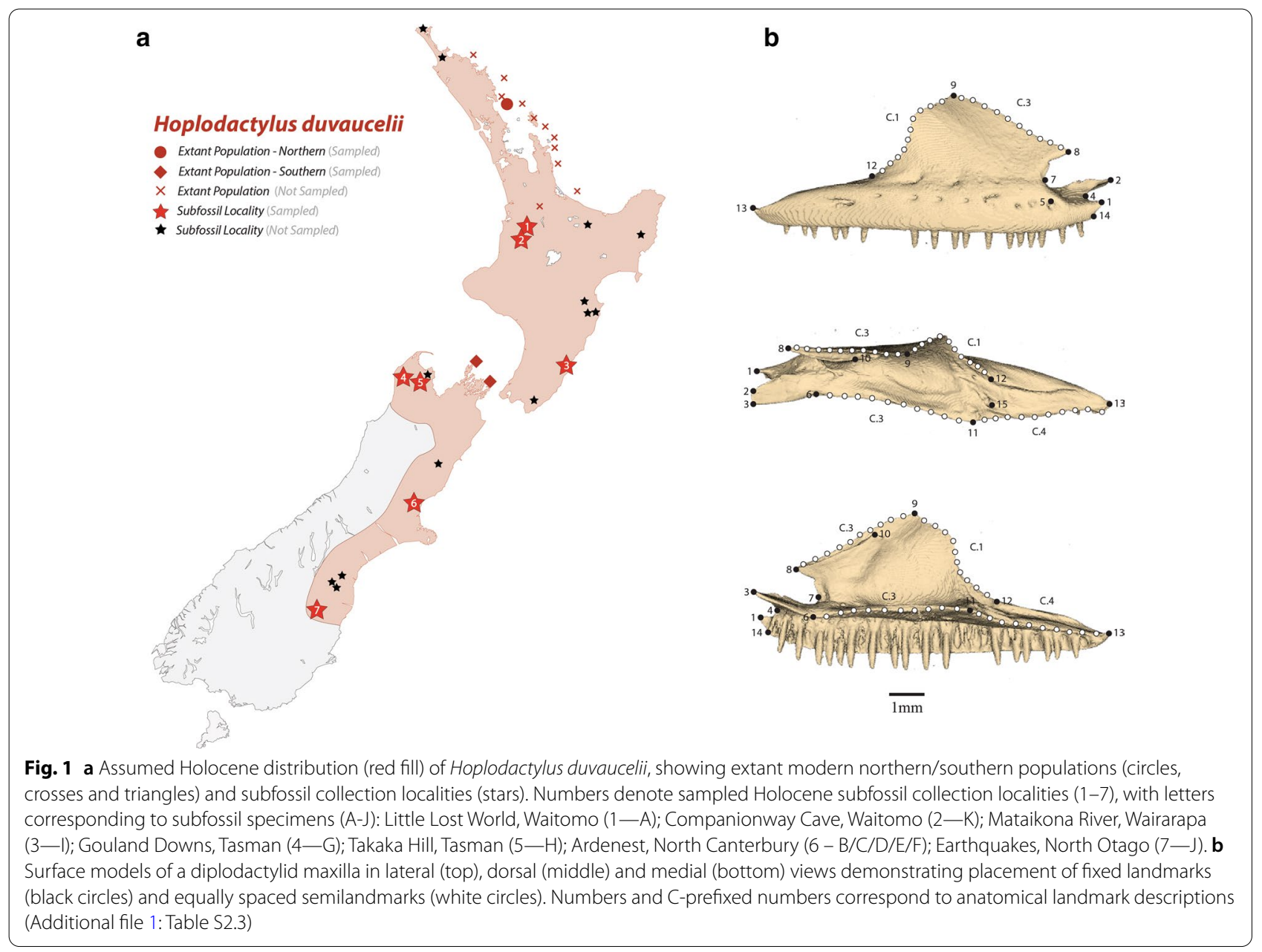


in New Zealand [26, 27] implies unrecognized diversity may exist within ' $H$. $c f$. duvaucelii'; perhaps detectable through fine-scale osteological analysis. Geometric morphometrics [36], a method of statistical shape analysis that enables improved detection and visualisation of subtle morphological differences (compared with traditional linear-based morphometrics [37, 38]), has been widely applied in herpetofaunal studies; including the successful discrimination of closely-related species [39-41] and classification [42-44] of isolated cranial elements. We therefore predict osteological differences, if examined appropriately (using geometric morphometrics), will be sufficient for discriminating between extant diplodactylid genera (and potentially species), enabling the identification of isolated subfossil material, or reveal unidentified taxa that require description and diagnosis.

Herein, three-dimensional geometric morphometrics is used to characterise and quantify both shape and size variation in the maxilla of modern New Zealand diplodactylid genera (Dactylocnemis, Hoplodactylus, Mokopirirakau, Naultinus and Woodworthia), for comparison with Holocene ' $H$. cf. duvaucelii' subfossils. Three main research questions are tested: (a) can recognised diplodactylid genera be distinguished based on maxilla shape; (b) is size a reliable method for generic-level identification of isolated cranial elements; and (c) have cryptic extinctions occurred in the Diplodactylidae (with a focus on ' $H$. cf. duvaucelii')?

\section{Results}

Principal axes of diplodactylid maxilla variation

Principal component (PC) analysis of landmarked maxillae (Fig. 1b) reveals the majority (71.5\%) of shape variability among extant New Zealand diplodactylids is concentrated in four dimensions (Fig. 2a; Additional file 1: Figure S3). Subsequent PC contributions (PC5PC54) are either small or negligible $(<5.0 \%)$, and thus not considered further.
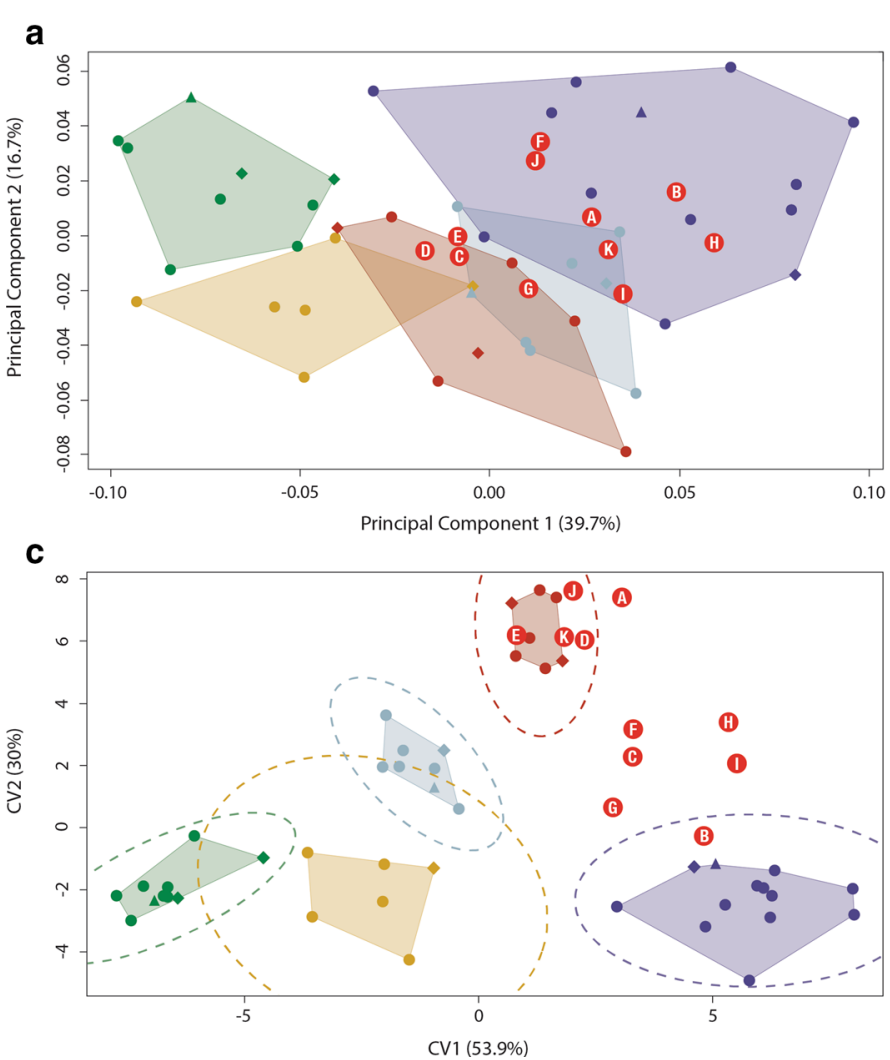

b

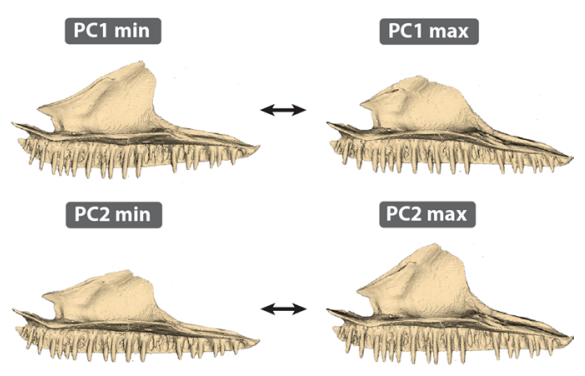

d

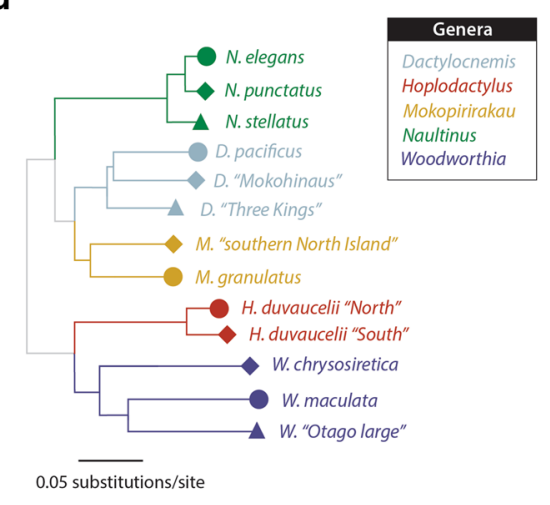

Fig. 2 a Principal component $(P C)$ analysis of maxilla shape showing PC1 versus PC2 (representing $56.4 \%$ of variation in maxilla shape). b Surface warps representing the maxima and minima shape differences of PC1/PC2 axes (see A). c Canonical variates (CV) analysis showing CV1 versus CV2 (representing $83.9 \%$ of the total among-group variance) with 95\% confidence ellipses plotted for each genus. $\mathbf{d}$ Phylogenetic tree of described/ undescribed diplodactylid species analysed (adapted from $[2,18]$ ). Points in (A) and (C) are modern individuals (symmetric component of left-right maxilla shape) coloured by genus (Dactylocnemis: blue-grey, Hoplodactylus: red, Mokopirirakau: yellow, Naultinus: green, Woodworthia; purple) and bounded by convex hulls, with shapes (circle, diamond, triangle) corresponding to species shown in (D). Holocene subfossil individuals are shown as red circles (A-J): Waitomo (A: AU7700, K: WO333), Wairarapa (I: S.46528.1), Tasman (G: S.38813.2; H: S.39086), North Canterbury (B: S.33703.2, C: S.33703.3, D: S.33703.4, E: S.33703.7, F: S.33703.8) and North Otago (J:VT791a) 
PC1, the primary axis of maxilla shape variation (39.7\%), largely pertains to differences in shape of the nasal and orbital margins (Fig. 2b; Additional file 1: Figure S4). Negative PC1 values are associated with an elongate nasal margin and adjacent medial flange; more concave prefrontal and orbital margins; and a more convex palatal shelf. Naultinus and Mokopirirakau granulatus (i.e. excluding the $M$. 'southern North Island' specimen-see below) form distinct clusters in the negative region of $\mathrm{PC} 1$, whereas Dactylocnemis, Hoplodactylus and Woodworthia primarily occupy overlapping intermediate regions of the positive zone (Fig. 2a).

PC2 (16.7\% of variance) describes differences associated with overall element robustness, with dorsoventrally shallow, laterally slender maxillae along the negative sector of the axis, contrasting with dorsoventrally deep, laterally broad maxillae along the positive region of the axis (Fig. 2b; Additional file 1: Figure S4). Two morphologically distinct generic clusters form along this axis: robust maxillae (Naultinus-Woodworthia) and gracile maxillae (Dactylocnemis-Hoplodactylus-Mokopirirakau; Fig. 2a).

PC3 (8.0\% of variance) describes shape differences in both the anterolateral lappet and prefrontal margin (Additional file 1: Figure S4); with dorsoventral thickening (and lateral thinning) of the anterolateral lappet and plateauing of the prefrontal margin at negative values. Conversely, at positive values, the prefrontal margin forms a near continuous curve with the adjacent orbital margin (Additional file 1: Figure S4). Shape differences along PC4 (7.2\%) are primarily associated with increased curvature of the tooth row along the negative sector of the axis (Additional file 1: Figure S4).

Visually, Holocene subfossil specimens cluster in the intermediate region of the positive zones of $\mathrm{PC} 1, \mathrm{PC} 2$ and PC4; overlapping the morphospaces of extant genera (Fig. 2a; Additional file 1: Figure S3). Conversely, Holocene subfossil specimens (excluding $\mathrm{H}$ ) occupy increasingly positive regions of $\mathrm{PC}$, with some individuals $(\mathrm{B}, \mathrm{E}$, I, J) exhibiting no overlap with extant genera (Additional file 1: Figure S3). Procrustes distances of the Holocene subfossil specimens (Additional file 1: Table S4) across all PC axes suggest shape similarities with Dactylocnemis (E, K), Hoplodactylus (A, C, D, G, I, J) and Woodworthia (B, F, H), with no shape similarities with Mokopirirakau or Naultinus.

\section{Predictors of shape and size}

Procrustes ANOVA (Additional file 1: Table S5) revealed that phylogenetic affiliation (i.e. genus) is a highly significant predictor $\left(\mathrm{F}_{(4,38)}=9.01, p<0.001\right)$ of maxilla shape, accounting for $45.2 \%$ of the shape variation. Multivariate pairwise post-hoc tests indicate differences to be significant between most genera $(p<0.05)$, excluding Dactylocnemis-Hoplodactylus $(p=0.229)$, and Hoplodactylus-Mokopirirakau $(p=0.056)$ comparisons (Additional file 1: Table S6). A weak but significant relationship also exists between maxilla shape and centroid size $\left(\mathrm{F}_{(1,41)}=5.39, p=0.020\right)$, and their interaction $\left(\mathrm{F}_{(4,38)}=1.35, p=0.023\right.$; Additional file 1: Table S5), suggesting a small proportion of the shape diversity $(6.8 \%)$ is due to allometry.

One-way ANOVA (Additional file 1: Table S7) identified significant differences in maxilla centroid size between genera $\left(\mathrm{F}_{(4,38)}=32.22, p<0.001\right)$, with Hoplodactylus ( $1690 \pm 228.1$; mean $\pm \mathrm{sd}$ ) being significantly larger under all HSD post-hoc comparisons (Additional file 1: Table S8). Additionally, Woodworthia $(968 \pm 100.9)$ is significantly smaller than most other genera (Additional file 1: Figure S5; Table S8), excluding the NaultinusWoodworthia comparison $(p=0.253)$. Conversely, Dactylocnemis (1198 \pm 142.9$)$, Mokopirirakau (1241 \pm 115.6$)$ and Naultinus $(1093 \pm 104.0)$ are indistinguishable from each other based on centroid size alone. Subfossil specimens show no overlap with the error bars of nonHoplodactylus maxillae, with some $(\mathrm{G}=2042, \mathrm{H}=2086$, $\mathrm{I}=2024, \mathrm{~K}=2316$ ) extending beyond the maximum extant Hoplodactylus maxilla centroid size (Additional file 1: Figure S5).

\section{Phylogenetic shape differences}

Phylogenetic signal in maxilla shape is statistically significant $\left(\mathrm{K}_{\text {mult }}=0.828, p<0.001\right)$; however, species resemble each other less than expected under a model of Brownian motion (given $K_{\text {mult }}$ is less than 1). This is reflected in the distribution of species throughout the phylomorphospace (Additional file 1: Figure S6), with several overlapping branches (e.g. Dactylocnemis and Hoplodactylus) and non-adjacent closely related species (e.g. M. granulatus and $M$. 'southern North Island').

Canonical variate (CV) analysis (Fig. 2c) and Mahalanobis distance probabilities (Additional file 1: Table S9) show all genera form significantly different groups, with a cross-validation accuracy of $100 \%$. Canonical function 1 (CV1; 53.9\% among-group variance) clearly distinguishes Naultinus and Woodworthia, which occupy opposite extremes of the morphospace (Fig. 2c). The positive sector of CV1 describes shortening of the nasal margin and adjacent medial flange, with corresponding shortening in the prefrontal margin (similar to PC1; Additional file 1: Figure S7). Hoplodactylus occupies the extreme positive region of canonical function 2 (CV2; 30\% among-group variance), characterized by a relative slope decrease of the nasal margin and consequent shortening of the orbital margin (Fig. 2c; Additional file 1: Figure S7).

The Holocene subfossil specimens are broadly distributed throughout the positive zones of CV1 and CV2 
(Fig. 2c), with some individuals visually falling within the 95\% confidence-interval of the morphospaces of extant genera (Hoplodactylus: D, E, J, K; Woodworthia: B). Typicality probabilities of Mahalanobis distances across all CVs (Table 1) show that while many Holocene subfossil specimens strongly associate with Hoplodactylus (A, D, E, F, J, K), other specimens (B, C, G, H, I) show no clear phylogenetic affinities, indicating that Holocene subfossil specimens display greater variation in maxillary form than that encompassed by the extant genera. Conversely, despite posterior probabilities (Table 1) showing similar significant support for Holocene subfossil Hoplodactylus classification (A, C, D, E, F, H, J, K), specimens with lower typicality probabilities were assigned to Woodworthia (B, G, I).

\section{Discussion}

Variation and morphological convergence in diplodactylid maxillae

Phylogenetic position is a significant predictor of maxilla shape diversity in New Zealand diplodactylids, with all genera (Dactylocnemis, Hoplodactylus, Mokopirirakau, Naultinus and Woodworthia) being morphologically distinct. Identification of taxonomically informative morphological variation within a single skeletal element contrasts with previous assertions of skeletal uniformity in New Zealand's geckos (e.g. [23, 26]).

Variation in diplodactylid maxilla shape is predominantly explained by two characters, described by the first two axes of both PCA and CVA: (a) posterior extension/reduction of the nasal margin; and (b) increase/ decrease in dorsoventral extent of the facial process. Separation of genera along PC1 appears correlated with broad habitat use of New Zealand diplodactylids, with terrestrial-arboreal (Dactylocnemis, Hoplodactylus and Woodworthia) and exclusively arboreal (Naultinus) genera occupying positive and negative regions respectively $[45,46]$. This morphological signature of habitat use extends to species-level comparison, most notably for discrimination of the terrestrial-arboreal $M$. 'southern North Island' from the arboreal M. granulatus [47], characterized by a shift to more positive values.

In lizards, arboreal forms tend towards broad, pointed skulls, and, similar to saxicoline species, tend to be dorsoventrally flattened, presumably enabling faster climbing speeds on non-horizontal surfaces [48-50]. While cranial modifications associated with habitat use are undocumented for New Zealand diplodactylids, extension of the nasal margin in arboreal species appears to be linked to two superficial morphological changes in the adjacent prefrontal margin: (a) a reduction in anterior extent (observed in other Gekkota; [51]); and (b) formation of a thickened ridge along the prefrontal orbital margin (Additional file 1: Figure S8). While the function of these features remains unclear, association with arboreality may indicate ecomorphological convergence between phylogenetically independent lineages. Despite describing similar shape change, separation of genera along CV1 reflects broad phylogenetic relationships, distinguishing broad (Hoplodactylus, Woodworthia) and narrow (Dactylocnemis, Mokopirirakau, Naultinus) toed clades by positive and negative values respectively; supporting previous morphological classification [16].

In addition to habitat use, skull-shape evolution in lizards is strongly influenced by diet, with shape variation concentrated in the premaxilla, nasal and jaw joint, reflecting their roles in jaw-based prehension and feeding biomechanics $[48,52]$. Herbivorous lizard skulls tend

Table 1 Typicality and posterior probabilities of Holocene subfossil specimens belonging to extant genera, calculated using Mahalanobis distances

\begin{tabular}{|c|c|c|c|c|c|c|c|c|c|c|c|}
\hline & & \multicolumn{5}{|c|}{ Typicality probabilities } & \multicolumn{5}{|c|}{ Posterior probabilities } \\
\hline & & D & $\mathbf{H}$ & M & $\mathbf{N}$ & w & $\bar{D}$ & $\mathbf{H}$ & M & $\mathbf{N}$ & w \\
\hline A & AU7700 & 0.026 & 0.215 & 0.020 & 0.018 & 0.033 & $<0.001$ & 1 & $<0.001$ & $<0.001$ & $<0.001$ \\
\hline B & S.33703.2 & 0.013 & 0.030 & 0.021 & 0.013 & 0.041 & $<0.001$ & $<0.001$ & $<0.001$ & $<0.001$ & 0.999 \\
\hline C & S.33703.3 & 0.031 & 0.110 & 0.046 & 0.026 & 0.070 & $<0.001$ & 0.999 & $<0.001$ & $<0.001$ & $<0.001$ \\
\hline D & S.33703.4 & 0.257 & 0.688 & 0.096 & 0.046 & 0.122 & $<0.001$ & 1 & $<0.001$ & $<0.001$ & $<0.001$ \\
\hline E & S.33703.7 & 0.570 & 0.819 & 0.133 & 0.072 & 0.120 & $<0.001$ & 0.999 & $<0.001$ & $<0.001$ & $<0.001$ \\
\hline $\mathrm{F}$ & S.33703.8 & 0.157 & 0.557 & 0.125 & 0.060 & 0.286 & $<0.001$ & 0.999 & $<0.001$ & $<0.001$ & $<0.001$ \\
\hline G & S.38813.2 & 0.031 & 0.060 & 0.054 & 0.024 & 0.061 & $<0.001$ & 0.019 & 0.004 & $<0.001$ & 0.809 \\
\hline $\mathrm{H}$ & S.39086 & 0.041 & 0.167 & 0.043 & 0.020 & 0.114 & $<0.001$ & 0.999 & $<0.001$ & $<0.001$ & $<0.001$ \\
\hline | & S.46528.1 & 0.028 & 0.091 & 0.044 & 0.016 & 0.090 & $<0.001$ & 0.049 & $<0.001$ & $<0.001$ & 0.512 \\
\hline J & VT791a & 0.078 & 0.205 & 0.027 & 0.022 & 0.038 & $<0.001$ & 1 & $<0.001$ & $<0.001$ & $<0.001$ \\
\hline K & WO333 & 0.177 & 0.742 & 0.088 & 0.050 & 0.105 & $<0.001$ & 1 & $<0.001$ & $<0.001$ & $<0.001$ \\
\hline
\end{tabular}

Highest typicality $(p>0.20)$ and posterior probabilities for each Holocene subfossil specimen are indicated in bold 
towards reduced snout lengths and high temporal regions relative to carnivorous lizards, contributing to increased bite strength required for processing fibrous and tough foliage [53-55]. Conversely, omnivorous gekkotans represent intermediate forms not specialized for particular feeding behaviors, and consequently lack unique morphological adaptations [56]. New Zealand geckos are predominantly omnivorous, consuming a wide variety of food items, including plant matter (fruit, honeydew and nectar) and arthropods [46]. Such extensive dietary overlap affects the use of diet as a variable of maxilla shape, given that the categories (omnivorous and insectivorous) are not discrete.

Finally, as lizard maxillae are evolutionarily conserved, exhibiting reduced disparity relative to rate of evolution (compared with other cranial elements; [52]); similar analyses of elements critical to cranial biomechanics (e.g. quadrate, which also supports the auditory system) may enhance detection of stronger species-level morphological signals in the New Zealand Diplodactylidae.

\section{Efficacy of size-based discrimination}

Maxilla size is significantly correlated with phylogenetic affinity; however, only Hoplodactylus can be fully differentiated (under post-hoc comparisons), with the remaining diplodactylid genera exhibiting variable degrees of overlap. This highlights the inefficiency of previous sizebased taxonomic identification of non-Hoplodactylus Holocene subfossil geckos, especially intermediate-sized genera (Dactylocnemis, Mokopirirakau and Naultinus), which exhibit complete size overlap. Similarly, while large size proves reliable in discriminating extant $H$. duvaucelii, application to Holocene subfossil identification requires assumptions of temporal taxonomic homogeneity (or "covert biases"; [57]).

Previous analyses of squamate genera including Anolis $[58,59]$ and Iguana $[60]$ have shown maxillae to be effective predictors of snout-vent length (SVL). Our results exhibit similar trends both between and within diplodactylid genera, with mean genus centroid size reflecting relative SVL [61], and larger species (N. punctatus, D. 'Three Kings') having increased centroid sizes relative to smaller congeners (N. elegans, D. pacificus; $[62,63])$.

\section{Increased Holocene diversity of large geckos}

Our results provide evidence for increased morphological diversity of large geckos during the Holocene in New Zealand, with declines in both shape and size variation following Polynesian and European colonization. This suggests that well-characterized biodiversity reductions (and extinctions) observed across insular avifauna [64, 65 ] extend to lineages comprised of taxa of smaller body size, including herpetofauna.
Combined Procrustes and Mahalanobis distance comparisons provide support for previous size-based assignment of five Holocene subfossils (A, D, E, J, K) to $H$. duvaucelii, confirming assumed prehuman distribution of this species across both the North and South Islands. The remaining six Holocene subfossil specimens (B, C, F, G, H, I) exhibit classificatory discrepancies and/or reduced assignment probabilities (below relevant thresholds), reflected by their unique position across CV1/CV2. These distinct Holocene subfossil maxillae ("unknown taxa") do not reflect differential adaptation of $H$. duvaucelii to mainland and island habitats (given shape overlap of mainland and island populations) but reflect either increased morphological diversity of mainland large species (not encompassed by extant populations) or the presence of at least one extinct, large, broad-toed diplodactylid species.

Based on digit morphology, the extinct giant $H$. delcourti was positioned within the broad-toed clade, sister to $H$. duvaucelii [20], suggesting these "unknown taxa" could potentially represent small or even juvenile $\mathrm{H}$. delcourti. However, this seems unlikely given the paucity of reported subfossil remains of $H$. delcourti [66], despite extensive collections of other diplodactylid taxa [26]. More precise phylogenetic affinities of both $H$. delcourti and "unknown taxa" could be determined through future ancient DNA analysis.

During the Holocene, mainland $H$. duvaucelii (and "unknown taxa") reached larger sizes than extant populations, reflected in a reduction in maximum maxilla size (a proxy for body size; e.g. [58]). Such sized-biased extinction is well-documented for Quaternary insular lizards globally [59, 67-69], including the extinction of two largebodied eugongyline skink species (Oligosoma northlandi and Oligosoma sp.) in northern New Zealand [25, 27, 70]. This reflects the inherent vulnerability of New Zealand's large-bodied, nocturnal herpetofauna to high predation rates and ecological displacement by exotic mammals (including the Pacific rat Rattus exulans (kiore); [71, 72]), particularly in forest-cleared environments [73]. Smaller lizards can escape predation during periods of inactivity through utilizing narrow retreats, given limited overlap in body diameter with small mammalian predators [45]. Conversely, refugia utilized by large-bodied lizards can be accessed by mammalian predators, as evidenced by reductions in body weight, tail width and recruitment of H. duvaucelii on kiore-inhabited islands [34, 74].

Similarly to extant $H$. duvaucelii populations [75], Holocene subfossil $H$. duvaucelii also exhibit a latitudinal cline in maxilla size, in opposition to Bergmann's rule (i.e. increased size at higher latitudes), with individuals from northern localities being noticeably larger than those from southern localities. For diurnal lizards, reduced 
body size appears to be an advantageous thermoregulatory strategy in cooler climates, with high surface-area to volume ratio permitting rapid heat gain whilst sunbasking [76, 77]. Despite being nocturnal, Duvaucel's gecko occasionally emerges from retreats to thermoregulate through cryptic sun-basking [78, 79], suggesting that small body size provides an adaptive advantage at high latitudes.

\section{Conclusions}

The majority of New Zealand diplodactylid genera can be differentiated from each other based exclusively upon the shape of the maxilla, which exhibits strong correlations with phylogenetic relationships. Additional species-level discrimination based on ecomorphological adaptations highlights the potential application of geometric morphometrics to the morphological characterization of highly functionally variable elements (or whole skulls) in taxonomic descriptions of extant diplodactylid species. Previous sized-based identification of Holocene subfossils is ineffective and underestimates extinct diversity, suggesting global assemblages of insular reptiles are depauperate in comparison to their prehuman diversity.

\section{Methods}

\section{Specimen selection}

To capture extant morphological variation, we examined both left and right maxillae (sensu [80]) from 43 adult skeletal specimens (Additional file 1: Table S1) representing 13 species from five diplodactylid genera: Dactylocnemis, Hoplodactylus, Mokopirirakau, Naultinus and Woodworthia (Additional file 1: Figure S1, Table S1). In addition, we examined 11 well-preserved Holocene subfossil maxillae identified as 'Hoplodactylus cf. duvaucelii', covering the majority of their (assumed) prehuman range (Fig. 1a; Additional file 1: Table S1). Maxillae were utilized primarily due to their relative abundance in subfossil deposits (Scarsbrook pers. obs.), compared with more osteologically informative elements (e.g. quadrate; [81, 82]). For additional specimen selection details see Additional file 1: Methods.

\section{Geometric morphometrics}

Geometric morphometric analyses were performed on a total of 94 maxillae (see Additional file 1: Methods for additional analytical details). Three-dimensional rendered surface models were generated from microCT reconstructions of maxillae, with shape characterized by 15 landmarks and 40 sliding semi-landmarks (Fig. 1b; Additional file 1: Figures S2, Table S2) digitized in Checkpoint (Stratovan Corporation, Davis, CA). Landmark coordinates were aligned using a generalized least-squares Procrustes superimposition [38], with semi-landmark position optimized using the Procrustes distance criterion [83] and paired elements symmetrized (following mirroring of left maxillae coordinates; Additional file 1: Table S3).

Shape variation in maxillae of the extant species was assessed using principal component analysis (PCA); with intergeneric differences (shape $\sim$ genus * size) tested using a Procrustes analysis of variance (ANOVA; [84]), and visualized using canonical variate analysis (CVA; [85]) with cross-validations, based on a reduced set of PC scores $[86,87]$. Three-dimensional surface warps [88] representing minimum and maximum shapes along both principal component $(\mathrm{PC})$ and canonical variate $(\mathrm{CV})$ axes were generated using the thin-plate spline (TPS) method [87, 89]. Phylogenetic signal in maxilla shape was calculated using $\mathrm{K}_{\text {mult }}$ [90, 91], with statistical significance determined using phylogenetic permutation (tree inferred from [2, 18]; Fig. 2d) with 1000 iterations [92]. Interspecific phylogeny-associated shape variation was visualized across the first two PC axes [92].

Holocene subfossil maxillae were then projected into these two-dimensional morphospaces (i.e. PCA and CVA) through matrix multiplication with respective eigenvectors (e.g. [93]). Phylogenetic classification of Holocene subfossil specimens was performed through Procrustes and Mahalanobis distance comparisons (to the mean maxilla shape of each genus), with the latter used to calculate typicality [94, 95] and posterior [96] probabilities Variation in size of the maxilla (represented as centroid-size of the landmark configuration) between genera was examined using a one-way ANOVA and Tukey's honestly significant difference (HSD) post-hoc tests [97], and visualised using a barplot. All statistical analyses were performed in the $\mathrm{R}$ statistical environment $\mathrm{v}$. 3.6.1 [98] using the packages geomorph v. 3.1.2 [92] and Morpho v. 2.7 [99].

\section{Supplementary Information}

The online version contains supplementary material available at https://doi. org/10.1186/s12862-021-01808-7.

Additional file 1. Supplementary methods, figures (S1-S8) and tables (S1-S8).

Additional file 2. Three-dimensional landmark coordinates for modern and subfossil maxilla.

Additional file 3. $\mathrm{R}$ code for geometric morphometric and statistical analyses.

\section{Acknowledgements}

We thank the following New Zealand institutions: Auckland Museum (Ruby Moore and Matt Rayner), Otago Museum (Cody Phillips), Museum of New Zealand Te Papa Tongarewa (Alan Tennyson and Tom Schultz) and Waitomo Caves Museum (Bridget Mosely), for access to comparative specimens. We are also very grateful to Andrew McNaugton (Otago Micro and Nanoscale Imaging) for assistance with micro-CT scanning; Ludovic Dutoit (University of 
Otago) for coding assistance; and both Aaron Bauer (Villanova University) and Daniel Paluh (University of Florida) for access to diplodactylid cranial scans. In addition, we would like to thank both Alexander Verry and Kerry Walton (both University of Otago) for manuscript review. We would also like to thank reviewers 1 (Anonymous) and 2 (Jendrian Riedel) for their constructive comments on our manuscript.

\section{Authors' contributions}

LS and NR conceived the study; LS carried out data collection and analyses with assistance from ES; ES, RH and NR assisted with data interpretation; LS drafted the manuscript, and all authors edited the manuscript; NR provided funding. All authors read and approved the final manuscript.

\section{Funding}

This work was supported by the Departments of Geology and Zoology, University of Otago; and a Royal Society of New Zealand Marsden FastStart Grant (16-UOO-096).

\section{Availability of data and materials}

The dataset (i.e. raw landmark coordinates and R-code) supporting the conclusions of this article is included within the article and its Additional file 2 and Additional file 3.

\section{Declarations}

\section{Ethics approval and consent to participate}

Not applicable.

\section{Consent for publication}

Not applicable.

\section{Competing interests}

Not applicable.

\section{Author details}

'Otago Paleogenetics Laboratory, Department of Zoology, University of Otago, Dunedin, New Zealand. ${ }^{2}$ School of Biological Sciences, The University of Adelaide, Adelaide, South Australia, Australia. ${ }^{3}$ Department of Conservation, Wellington, New Zealand.

Received: 5 February 2021 Accepted: 23 April 2021

Published online: 27 April 2021

\section{References}

1. Chapple DG, Hitchmough RA. Biogeography of New Zealand lizards. New Zealand Lizards. Berlin: Springer; 2016. p. 109-31. doi:https://doi.org/10. 1007/978-3-319-41674-8_5.

2. Nielsen SV, Bauer AM, Jackman TR, Hitchmough RA, Daugherty CH. New Zealand geckos (Diplodactylidae): Cryptic diversity in a postGondwanan lineage with trans-Tasman affinities. Mol Phylogenet Evol. 2011;59(1):1-22.

3. Daugherty CH, Gibbs GW, Hitchmough RA. Mega-island or micro-continent? New Zealand and its fauna. Trends in ecology and evolution, vol. 8. New York: Elsevier; 1993. p. 437-42.

4. Skipwith PL, Bi K, Oliver PM. Relicts and radiations: Phylogenomics of an Australasian lizard clade with east Gondwanan origins (Gekkota: Diplodactyloidea). Mol Phylogenet Evol. 2019;140:106589.

5. Hitchmough RA, Nielsen SV, Lysaght JA, Bauer AM. A new species of Naultinus from the Te Paki area, northern New Zealand. Zootaxa. 2021;4915(3):389-400. https://doi.org/10.11646/zootaxa.4915.3.7.

6. Hitchmough RA, Nielsen SV, Bauer AM. Earning your stripes: a second species of striped gecko in the New Zealand gecko genus Toropuku (Gekkota: Diplodactylidae). Zootaxa. 2020;4890(4):578-88.

7. Doughty P, Hutchinson MN. A new species of Lucasium (Squamata: Diplodactylidae) from the southern deserts of Western Australia and South Australia. Rec West Aust Museum. 2008;25:95-106. https://doi.org/10. 18195/issn.0312-3162.25(1).2008.095-106.
8. Vanderduys E. A new species of gecko (Squamata: Diplodactylidae: Strophurus) from north Queensland. Australia Zootaxa. 2016;4117(3):341-58. https://doi.org/10.11646/zootaxa.4117.3.3.

9. Bauer AM, Jackman T, Sadlier RA, Whitaker AH, Anthony H. A new genus and species of diplodactylid gecko (Reptilia: Squamata: Diplodactylidae) from Northwestern New Caledonia. Pacific Sci. 2006;60(1):125-36. https://doi.org/10.1353/psc.2005.0055.

10. Bauer AM, Whitaker AH, Sadlier RA. Two new species of the genus Bavayia (Reptilia: Squamata: Diplodactylidae) from New Caledonia. Southwest Pacific Pacific Sci. 1998;52(4):342-55.

11. Bauer AM, Jackman TR, Sadlier RA, Shea G, Whitaker AH. A new smallbodied species of Bavayia (Reptilia: Squamata: Diplodactylidae) from Southeastern New Caledonia. Pacific Sci. 2008;62(2):247.

12. Stephenson N, Stephenson E. The osteology of the New Zealand geckos and its bearing on their morphological status. Trans R Soc New Zeal. 1955;84(2):341-58.

13. McCann C. The lizards of New Zealand. Dom Museum Bull. 1955;17:1-127.

14. Hitchmough RA, Patterson GB, Chapple DG. Putting a name to diversity: Taxonomy of the New Zealand lizard fauna. Berlin: Springer; 2016. p. 87-108. doi: https://doi.org/10.1007/978-3-319-41674-8_4.

15. Daugherty CH, Patterson GB, Hitchmough RA. Taxonomic and conservation review of the New Zealand herpetofauna. New Zeal J Zool. 1994;21 (4):317-23. https://doi.org/10.1080/03014223.1994.9518002.

16. Hitchmough RA. A systematic revision of the New Zealand Gekkonidae. Victoria University of Wellington; 1997.

17. Chambers GK, Wee Ming B, Buckley TR, Hitchmough RA. Using molecular methods to understand the Gondwanan affinities of the New Zealand biota: three case studies. Aust J Bot. 2001;49(3):377-87. https://doi.org/10.1071/BT00021.

18. Chong N. Phylogenetic analysis of the endemic New Zealand gecko species complex Hoplodactylus pacificus using DNA sequences of the 16S rRNA gene. New Zealand.: Victoria University; 1999.

19. Bauer A. Phylogenetic systematics and biogeography of the Carphodactylini (Reptilia: Gekkonidae). Bonn Zool Bull. 1990;30:1-218.

20. Russell AP, Bauer AM. The giant gecko Hoplodactylus delcourti and its relations to gigantism and insular endemism in the Gekkonidae. Bull Chicago Herpetol Soc. 1986;26:26-30.

21. Daza JD, Bauer AM, Snively ED. On the fossil record of the Gekkota. Anat Rec. 2014;297(3):433-62. https://doi.org/10.1002/ar.22856.

22. Lee MSY, Hutchinson MN, Worthy TH, Archer M, Tennyson AJD, Worthy $\mathrm{JP}$, et al. Miocene skinks and geckos reveal long-term conservatism of New Zealand's lizard fauna. Biol Lett. 2009;5(6):833-7. https://doi.org/ 10.1098/rsbl.2009.0440.

23. Worthy TH, Holdaway RN. Quaternary fossil faunas from caves on Mt Cookson, North Canterbury, South Island, New Zealand. J R Soc New Zeal. 1995;25(3):333-70. https://doi.org/10.1080/03014223.1995.95174 94.

24. Chapple DG. The future of New Zealand lizard research. In: New Zealand Lizards. Berlin: Springer; 2016. p. 361-75. doi: https://doi.org/10. 1007/978-3-319-41674-8_14.

25. Worthy TH. Osteological observations on the larger species of the skink Cyclodina and the subfossil occurrence of these and the gecko Hoplodactylus duvaucelii in the North Island, New Zealand. New Zeal J Zool. 1987;14(2):219-29. https://doi.org/10.1080/03014223.1987.10422 992.

26. Worthy TH. A review of the fossil record of New Zealand lizards. In: New Zealand Lizards. Berlin: Springer; 2016. p. 65-86. doi: https://doi.org/10. 1007/978-3-319-41674-8_3.

27. Worthy TH. Fossil skink bones from Northland, New Zealand, and description of a new species of Cyclodina Scincidae. J R Soc New Zeal. 1991;21(4):329-48. https://doi.org/10.1080/03036758.1991.10420831.

28. Morgan-Richards M, Hinlo AR, Smuts-Kennedy C, Innes J, Ji W, Barry M, et al. Identification of a rare gecko from North Island New Zealand, and genetic assessment of its probable origin: a novel mainland conservation priority? J Herpetol. 2016;50(1):77-86. https://doi.org/10.1670/13-128.

29. Wilmshurst JM, Anderson AJ, Higham TFG, Worthy TH. Dating the late prehistoric dispersal of Polynesians to New Zealand using the commensal Pacific rat. Proc Natl Acad Sci USA. 2008;105(22):7676-80. https://doi. org/10.1073/pnas.0801507105. 
30. Worthy TH, Holdaway RN. Quaternary fossil faunas, overlapping taphonomies, and palaeofaunal reconstruction in North Canterbury, South Island, New Zealand. J R Soc New Zeal. 1996;26(3):275-361. https://doi.org/10, 1080/03014223.1996.9517514.

31. Worthy TH. Quaternary fossil fauna of South Canterbury, South Island, New Zealand. J R Soc New Zeal. 1997;27(1):67-162. https://doi.org/10. 1080/03014223.1997.9517528.

32. Worthy TH. Quaternary fossil faunas of Otago, South Island, New Zealand. J R Soc New Zeal. 1998;28(3):421-521. https://doi.org/10.1080/03014223. 1998.9517573.

33. Worthy TH, Holdaway RN. Quaternary fossil faunas from caves in Takaka Valley and on Takaka Hill, northwest Nelson, South Island, New Zealand. J R Soc New Zeal. 1994;24(3):297-391. https://doi.org/10.1080/03014223. 1994.9517474.

34. Christmas E. Interactions between Duvaucel's gecko (Hoplodactylus duvaucelii) and kiore (Rattus exulans). Dunedin: University of Otago; 1995.

35. Wallis GP, Trewick SA. New Zealand phylogeography: evolution on a small continent. Mol Ecol. 2009;18(17):3548-80. https://doi.org/10.1111/j.1365294X.2009.04294.x.

36. Bookstein FL. Morphometric tools for landmark data: geometry and biology. Cambridge: Cambridge University Press; 1991.

37. Rohlf J, Marcus LF. A revolution morphometrics. Trends in Ecology and Evolution, vol. 8. New York: Elsevier; 1993. p. 129-32.

38. Adams DC, Rohlf FJ, Slice DE. A field comes of age: geometric morphometrics in the 21st century. Hystrix Ital J Mammal. 2013;24(1):7-14. https://doi.org/10.4404/hystrix-24.1-6283.

39. Mangiacotti M, Limongi L, Sannolo M, Sacchi R, Zuffi M, Scali S. Head shape variation in eastern and western Montpellier snakes. Acta Herpetol. 2014;9(2):167-77.

40. Ivanović A, Aljančič G, Arntzen JW. Skull shape differentiation of black and white olms (Proteus anguinus anguinus and Proteus a. parkelj): an exploratory analysis with micro-CT scanning. Contrib Zool. 2019;82(2):107-14. https://doi.org/10.1163/18759866-08202004.

41. Gabelaia M, Tarkhnishvili D, Adriaens D. Use of three-dimensional geometric morphometrics for the identification of closely related species of Caucasian rock lizards (Lacertidae: Darevskia). Biol J Linn Soc. 2018;125(4):709-17. https://doi.org/10.1093/biolinnean/bly143.

42. Dollion AY, Cornette R, Tolley KA, Boistel R, Euriat A, Boller E, et al. Morphometric analysis of chameleon fossil fragments from the Early Pliocene of South Africa: a new piece of the chamaeleonid history. Sci Nat. 2015;102(1-2):1-14. https://doi.org/10.1007/s00114-014-1254-3.

43. Gray JA, McDowell MC, Hutchinson MN, Jones MEH. Geometric morphometrics provides an alternative approach for interpreting the affinity of fossil lizard jaws. J Herpetol. 2017;51 (3):375-82. https://doi.org/10.1670/ 16-145.

44. Easton LJ, Rawlence NJ, Worthy TH, Tennyson AJD, Scofield RP, Easton CJ, et al. Testing species limits of New Zealand's leiopelmatid frogs through morphometric analyses. Zool J Linn Soc. 2018;183(2):431-44. https://doi. org/10.1093/zoolinnean/zlx080.

45. Tingley R, Hitchmough RA, Chapple DG. Life-history traits and extrinsic threats determine extinction risk in New Zealand lizards. Biol Conserv. 2013;165:62-8.

46. Hare KM, Chapple DG, Towns DR, van Winkel D. The ecology of New Zealand's lizards. In: New Zealand Lizards. Berlin: Springer; 2016. p. 133-68. doi: https://doi.org/10.1007/978-3-319-41674-8_6.

47. Tingley R, Hitchmough RA, Chapple DG. Life-history traits and extrinsic threats determine extinction risk in New Zealand lizards. Biol Conserv. 2013;165:62-8.

48. Gray JA, Sherratt E, Hutchinson MN, Jones MEH. Evolution of cranial shape in a continental-scale evolutionary radiation of Australian lizards. Evolution. 2019;73(11):2216-29. https://doi.org/10.1111/evo.13851.

49. Revell LJ, Johnson MA, Schulte JA, Kolbe JJ, Losos JB. A phylogenetic test for adaptive convergence in rock-dwelling lizards. Evolution. 2007;61(12):2898-912. https://doi.org/10.1111/j.1558-5646.2007.00225.x.

50. Grismer LL, Grismer JL. A re-evaluation of the phylogenetic relationships of the Cyrtodactylus condorensis group (Squamata; Gekkonidae) and a suggested protocol for the characterization of rock-dwelling ecomorphology in Cyrtodactylus. Zootaxa. 2017;4300(4):486-504. https://doi. org/10.11646/zootaxa.4300.4.2.

51. Rieppel $\mathrm{O}$. The structure of the skull and jaw adductor musculature in the Gekkota, with comments on the phylogenetic relationships of the
Xantusiidae (Reptilia: Lacertilia). Zool J Linn Soc. 1984;82(3):291-318. https://doi.org/10.1111/j.1096-3642.1984.tb00645.x.

52. Watanabe A, Fabre AC, Felice RN, Maisano JA, Müller J, Herrel A, et al. Ecomorphological diversification in squamates from conserved pattern of cranial integration. Proc Natl Acad Sci USA. 2019;116(29):14688-97. https://doi.org/10.1073/pnas.1820967116.

53. Herrel A, Aerts P, De Vree F. Ecomorphology of the lizard feeding apparatus: a modelling approach. Netherlands J Zool. 1998;48(1):1-25. https:// doi.org/10.1163/156854298×00183.

54. Metzger KA, Herrel A. Correlations between lizard cranial shape and diet: a quantitative, phylogenetically informed analysis. Biol J Linn Soc. 2005;86(4):433-66. https://doi.org/10.1111/j.1095-8312.2005.00546.x.

55. Stayton CT. Testing hypotheses of convergence with multivariate data: morphological and functional convergence among herbivorous lizards. Evolution. 2006;60(4):824-41. https://doi.org/10.1111/j.0014-3820.2006. tb01160.x.

56. Daza JD, Herrera A, Thomas R, Claudio HJ. Are you what you eat? A geometric morphometric analysis of gekkotan skull shape. Biol J Linn Soc. 2009;97(3):677-707. https://doi.org/10.1111/j.1095-8312.2009.01242.x.

57. Bell CJ, Mead II. Not enough skeletons in the closet: collections-based anatomical research in an age of conservation conscience. Anat Rec. 2014;297(3):344-8. https://doi.org/10.1002/ar.22852.

58. Bochaton C, Kemp ME. Reconstructing the body sizes of Quaternary lizards using Pholidoscelis Fitzinger, 1843, and Anolis Daudin, 1802, as case studies. J Vertebr Paleontol. 2017;37(1):e1239626. https://doi.org/10.1080/ 02724634.2017.1239626.

59. Bochaton C, Bailon S, Herrel A, Grouard S, Ineich I, Tresset A, et al. Human impacts reduce morphological diversity in an insular species of lizard. Proc R Soc B Biol Sci. 1857;2017(284):20170921. https://doi.org/10.1098/ rspb.2017.0921.

60. Bochaton C. Describing archaeological Iquana laurenti, 1768 (Squamata: Iguanidae) populations: Size and skeletal maturity. Int J Osteoarchaeol. 2016;26(4):716-24. https://doi.org/10.1002/oa.2463.

61. van Winkel D, Baling M, Hitchmough R. Reptiles and amphibians of New Zealand. NZ: Auckland University Press; 2018.

62. Robb J, Hitchmough RA. Review of the genus Naultinus Gray (Reptilia: Gekkonidae). Rec Auckl Inst Museum. 1979;16:189-200.

63. Parrish GR, Gill BJ. Natural history of the lizards of the three kings Islands, New Zealand. New Zeal J Zool. 2003;30(3):205-20. https://doi.org/10. 1080/03014223.2003.9518339.

64. Walther M, Hume J. Extinct birds of Hawaii. Honolulu, HI: Mutual Publishing; 2016.

65. Tennyson A, Martinson P. Extinct Birds of New Zealand. Wellington: Te Papa Press; 2006.

66. Bauer A, Russell A. Osteological evidence for the prior occurrence of a giant gecko in Otago. New Zealand Cryptozool. 1988;7:22-37.

67. Kemp ME, Hadly EA. Extinction biases in Quaternary Caribbean lizards. Glob Ecol Biogeogr. 2015;24(11):1281-9. https://doi.org/10.1111/geb. 12366.

68. Bailon S, Bochaton C, Lenoble A. New data on Pleistocene and Holocene herpetofauna of Marie Galante (Blanchard Cave, Guadeloupe Islands, French West Indies): Insular faunal turnover and human impact. Quat Sci Rev. 2015:128:127-37.

69. Bochaton C, Grouard S, Cornette R, Ineich I, Lenoble A, Tresset A, et al. Fossil and subfossil herpetofauna from Cadet 2 Cave (Marie-Galante, Guadeloupe Islands, F. W. I.): Evolution of an insular herpetofauna since the Late Pleistocene. Comptes Rendus Palevol. 2015;14(2):101-10.

70. Gill BJ. Subfossil bones of a large skink (Reptilia: Lacertilia) from Motutapu Island. New Zealand Rec Auckl Inst Museum. 1985;22:69-76.

71. Whitaker AH. Lizard populations on islands with and without Polynesian rats Rattus exulans. Proc New Zeal Ecol Soc. 1973;20:121-30.

72. Towns DR, Daugherty $\mathrm{CH}$. Patterns of range contractions and extinctions in the New Zealand herpetofauna following human colonisation. New Zeal J Zool. 1994:21(4):325-39. https://doi.org/10.1080/03014223.1994. 9518003.

73. Towns DR. Response of lizard assemblages in the Mercury Islands, New Zealand, to removal of an introduced rodent: the kiore (Rattus exulans). J R Soc New Zeal. 1991;21(2):119-36. https://doi.org/10.1080/03036758. 1991.10431400. 
74. Hoare JM. Novel predators and naïve prey: how introduced mammals shape behaviours and populations of New Zealand lizards. Victoria University of Wellington; 2006

75. Cree A. Low annual reproductive output in female reptiles from New Zealand. New Zeal J Zool. 1994;21(4):351-72. https://doi.org/10.1080/ 03014223.1994.9518005.

76. Ashton KG, Feldman CR. Bergmann's rule in nonavian reptiles: Turtles follow it, lizards and snakes reverse it. Evolution. 2003;57(5):1151-63. https:// doi.org/10.1111/j.0014-3820.2003.tb00324.x.

77. Pincheira-Donoso D, Hodgson DJ, Tregenza T. The evolution of body size under environmental gradients in ectotherms: why should Bergmann's rule apply to lizards? BMC Evol Biol. 2008;8:68.

78. Barry M, Shanas U, Brunton DH. Year-round mixed-age shelter aggregations in Duvaucel's geckos (Hoplodactylus duvaucelii). Herpetologica. 2014;70(4):395-406.

79. Whitaker AH. The lizards of the Poor Knights Islands. New Zealand New Zeal J Sci. 1968;11:623-51.

80. Cardini A. Lost in the other half: Improving accuracy in geometric morphometric analyses of one side of bilaterally symmetric structures. Syst Biol. 2016;65(6):1096-106. https://doi.org/10.1093/sysbio/syw043.

81. Paluh DJ, Olgun K, Bauer AM. Ontogeny, but not sexual dimorphism, drives the intraspecific variation of quadrate morphology in Hemidactylus turcicus (Squamata: Gekkonidae). Herpetologica. 2018;74(1):22-8. https:// doi.org/10.1655/herpetologica-d-17-00037.1.

82. Paluh DJ, Bauer AM. Phylogenetic history, allometry and disparate functional pressures influence the morphological diversification of the gekkotan quadrate, a keystone cranial element. Biol J Linn Soc. 2018;125(4):693-708. https://doi.org/10.1093/BIOLINNEAN/BLY147.

83. Rohlf FJ, Slice D. Extensions of the procrustes method for the optimal superimposition of landmarks. Syst Zool. 1990;39(1):40. https://doi.org/10. 2307/2992207.

84. Adams DC. A method for assessing phylogenetic least squares models for shape and other high-dimensional multivariate data. Evolution. 2014;68(9):2675-88. https://doi.org/10.1111/evo.12463.

85. Albrecht $\mathrm{GH}$. Multivariate analysis and the study of form, with special reference to canonical variate analysis. Am Zool. 1980;20:679-93. https:// doi.org/10.1093/icb/20.4.679.

86. Strauss R. Discriminating groups of organisms. In: Elewa A, editor. Morphometrics for non morphometricians. Berlin: Springer; 2010. p. 73-91.
87. Mitteroecker P, Bookstein F. Linear discrimination, ordination, and the visualization of selection gradients in modern morphometrics. Evol Biol. 2011;38(1):100-14. https://doi.org/10.1007/s11692-011-9109-8.

88. Drake AG, Klingenberg CP. Large-scale diversification of skull shape in domestic dogs: Disparity and modularity. Am Nat. 2010;175(3):289-301.

89. Bookstein FL. Principal warps: thin-plate splines and the decomposition of deformations. IEEE Trans Pattern Anal Mach Intell. 1989;11(6):567-85.

90. Adams D. A generalized K statistic for estimating phylogenetic signal from shape and other high-dimensional multivariate data. Syst Biol. 2014;63(5):685-97. https://doi.org/10.1093/sysbio/syu030.

91. Blomberg SP, Garland T, Ives AR. Testing for phylogenetic signal in comparative data: behavioral traits are more labile. Evolution. 2003;57(4):71745. https://doi.org/10.1111/j.0014-3820.2003.tb00285.x.

92. Adams DC, Collyer M, Kaliontzopoulou A. geomorph: Software for geometric morphometric analyses. https://cran.r-project.org/web/packages/ geomorph/index.html. 2020

93. Dickson BV, Sherratt E, Losos JB, Pierce SE. Semicircular canals in Anolis lizards: ecomorphological convergence and ecomorph affinities of fossil species. R Soc Open Sci. 2017;4(10):170058. https://doi.org/10.1098/rsos. 170058.

94. Klecka W. Discriminant analysis. Newbury Park: Sage Publications; 1980.

95. Wilson SR. On comparing fossil specimens with population samples. J Hum Evol. 1981;10(3):207-14.

96. Albrecht $\mathrm{GH}$. Assessing the affinities of fossils using canonical variates and generalized distances. Hum Evol. 1992;7(4):49-69. https://doi.org/10. 1007/BF02436412.

97. Copenhaver M, Holland B. Computation of the distribution of the maximum studentized range statistic with application to multiple significance testing of simple effects. J Stat Comput Simul. 1988;30(1):1-15. https:// doi.org/10.1080/00949658808811082.

98. R Development Core Team. R: a language and environment for statistical computing. Vienna; 2019.

99. Schlager S. Morpho: calculations and visualizations related to geometric morphometrics. 2016

\section{Publisher's Note}

Springer Nature remains neutral with regard to jurisdictional claims in published maps and institutional affiliations.
Ready to submit your research? Choose BMC and benefit from:

- fast, convenient online submission

- thorough peer review by experienced researchers in your field

- rapid publication on acceptance

- support for research data, including large and complex data types

- gold Open Access which fosters wider collaboration and increased citations

- maximum visibility for your research: over $100 \mathrm{M}$ website views per year

At BMC, research is always in progress.

Learn more biomedcentral.com/submissions 